\title{
The Influence of the Great Depression on Economic Theory
}

\author{
Prof. Dr. Mark EYSKENS \\ Prof. at the Catholic University of Louvain.
}

The crisis of the thirties exercised on overwhelming influence on economic thought. The belief in a number of mechanisms to restore equilibrium was definitely shaken in the decade just before the second world war. So-called classical, liberally inspired economic theory was attacked and demolished by a new generation of economists, led by $\mathrm{J}$, M. Keynes, who saw it as being an unrealistic view of economic events.

Now, more than thirty years later, the radicalism of the Keynesian doctrine has undoubtedly been diluted and the blackwhite contrast between pre-Keynesian and Keynesian macro-economic theory now seems exaggerated. This does not alter the fact that the thirties, under the influence of events, then caused a Copernican reversal of many economic convictions. This has been particularly beneficial for economic theory.

Accurately measuring the influence of the "great depression" on economic thought is a very complex task. The following list contains the most important fields of economic theory altered directly or indirectly by the economic world crisis. This list obviously is not restrictive.

1. The Keynesian revolution as a consequence of a frontal attack on classical macro-economic theory.

2. A new interest theory and renewed views on monetary theories.

3. A renewed explanation of the trade-cycle.

4. A new theory of economic policy.

5. A new approach to economic systems;

a) : a critical analysis of liberalism and capitalism; 
b) the elaboration of a theory of economic interventionism and planning.

6. A new micro-economic analysis of market-structures and mechanisms; the rise of the theories of imperfect and monopolistic: competition.

7. The definition of macro-economic relations : national income: accounting and income analysis.

8. A strong expansion of empirical and statistical research; the: gradual application of econometrical téchniques.

9. The decay of the theory and practice of the International Gold Standard; the progressive elaboration of a Keynesian-inspired theory concerning balance of payments equilibrium.

10. A new turn in theoretical Welfare Economics; attempts to define a social welfare function.

It is impossible to elucidate thoroughly all the above mentioned: points in the frame of this article. Our attention therefore will go only: to the most relevant aspect of what is called "the new economics".

\section{The Keynesian Revolution.}

The life work of J. M. Keynes appeared in the year 1936 under the: title "The General Theory of Employment, Interest and Money." Shortly: after its publication it was generally recognized as one of the most important writıngs since the beginning of economic science. By 1930, the same author had drawn the attention of all economists with his book. "Treatise on Money." Keynes' reasoning begins with fundamental criticism of classical conceptions ${ }^{1}$ established so far.

a). This criticism implies that Keynes repudiates the well-known" "Loi des déboutchés" of the French classical author J...B. Say (1767-1832).

1) J. M. Keynes, however was not the first to criticize the classical. opinions (of A. Smith, D. Ricardo, J. S. Miil and followers) and more especially Say's law.

By 109 A. Aftalion "questioned the practical value of Say's law in hrs article "La réalité des surproductions générales." Revue d'Economie politique, 1909 - In the U.S.A. it seemed, that J. M. Clark appeared to have: been particularly sceptical ot the equilibrium-restoring mechanisms of the: economic system as it results from the logio of Say's law. 
The law of Say claims that every supply creates its own demand. Here one starts with the conviction that in a system of labor division every production necessitates the carrier with other goods and services. That explains the conclusion that income resulting from production will automatically stream through to demand. The consequence is that there is a principal balance between aggregate supply and aggregate demand. This also means that full employment is guaranteed.

In this typically liberal and optimistic view, overproduction, economic crisis and depressions are simply reasoned away. According to Say and most of the classical economists preceding him, inequalities between aggregate demand and aggregate supply are merely symptoms of friction which will shortly be neutralized by the market mechanism (i. e., the fluctuations of market-prices). Besides, in this opinion one assumes the quantity-theory of money whereby money is not expected to be esteemed for its own sake but only as an intermediate performer.

Keynes breaks with Say's theory, because for him money is not neutral. It performs an active part. The income earned by the production factors does not have to be spent completely; it can also be partly saved $^{3}$. Thus the possibility arises that aggregate demand could be smaller than aggregate output.

Conversely, aggregate demand can also be bigger than aggregate output, resulting from the influences of money creation and credit granting.

Keynes substitutes for Say's law an idea which is rather obvious and which had already been advocated by th Th. R. Maltuhs. He suggested that it is the aggregate demand which determines the production. By aggregate demand Keynes means chiefly the anticipated ex-ante demand as expected by the producers, from which the producers also anticipate their sale proceeds. When, according to Say, the relation between aggre-

2) Thus Say's law, that the aggregate demand price of output as a whole is equal to its aggregate supply price for all volumes of output, is aquivalent to the proposition that there, is no obstacle to full employment. (Keynes, General Theory, p. 26).

3) This statement should be connected with the Keynesian consumption-function which states that the average propensity to consume decreases according to the income-increase: in this way an increasing saving-gap develops. 
gate output and agregate demand ${ }^{4}$ is determined by the price mechanism, the relation, according to Keynes, between aggregate demand and aggregate output will be determined by the national income. One of the main characteristics of Keynes' reasoning is that income rather than price performs as an equilibrium-restoring factor.

b) Keynes not only rejected Say's law which was so important for classical liberal economy. He also criticized directly the logical consequences of Say's law concerning employment and the function accomplished by interest.

In these two matters he took up the problem which the great depression had violently brought to light.

The internal logic of Say's law had brought the classic and neoclassic and neo-classic economists to postulate that full employment is a "natural tendancy" of the economic system. A surplus on the labormarket, so they thought, should be normally reabsorbed by a real wagedecrease which, in turn, would stimulate the employment-demand. The unemployed therefore were laborers who refused to work at lower wages and who did not respect the rules of the market ${ }^{5}$. By virtue of this reasoning the unemployed were mainly unwilling laborers. Keynes showed that this classical logic, also advocated by his contemporary, Prof. A. Pigou ${ }^{8}$, was wrong because it was limited to the action of the microeconomic market mechanism.

In opposition to this, Keynes presented the possibility of mass unemployment as a consequence of the weakness of aggregate demand. For the first time it was stressed that unemployment can be permanent, even in a situation of economic equilibrium. This happens when the aggregate demand is equal to the aggregate output. From this, Keynes derived that the economic optimum may differ from the social optimum (i.e., full employment).

c) Finally Keynes was obliged, by the internal logic of his reasoning to reject the classical interest theory. According to the classical economists, interest appears as a market-price, bringing investments into

4) In principle the equality.

5) Expressed in the terminology of economic theory, this means that the laborers refuse to accept a wage which corresponds to their decreasing marginal product.

6) Pigou, A. C., Theory of unemyloyment, MacMillan, London 1933. 
line with savings. Keynes pointed out a few difficulties through which the classical mechanism can be dislocated. Speculative money demand (the demand for loanable funds) and liquidity-preference can have the consequence that the rate of interest can not go beneath the level necessary to bring the demand for investments to the level of complete employment. In Keynes' theory savings and investment are disjoined in large measure from the interest level. $\mathrm{He}$ sees savings and investment as functions of respectively income and the "marginal efficiency of capital." Saving no longer is a condition of investment. Saving becomes ex-post equal to investment, not via the interest mechanism but via changes in national income. The consequence of this view is the origin of the wellknown savings paradox. Savings threaten the development of the national income, if it does not stream through to demand. If savings are larger than investment then there exists a deflationary development, through which production will decrease to adjust the aggregate output to at a lower level to aggrogate demand.

If the above starting-points of Keynes are descrihed with such stress, it should make clear how greatly Keynes wanted to break with classical macro-economy ${ }^{7}$. The only classical author whose influence on Keynes was not in contrast, but who on the contrary, had shown remarkable pre- Keynesian intuitino, was Thomas Robert Malthus.

Besides it cannot be sufficiently underlined how greatly General "Theory was influenced by the events of the time, namely, the "great depression". Keynes did not search for the explanation of this chaotic and dramatic social and political phenomenon in the last convulsions of the dying capitalism as the Marxists did; neither is the greaat depression, according to Keynes, a simple business-cycle fluctuation. $\mathrm{He}$ interprets the great depression as initially a macro-economic disequilibrium. This disequilibrium tends however to a new balance through a strong contraction of economic activity.

The constructive contribution of Keynes' theory lies precisely in the renewed analyses he makes of the macro-economic working mechanism: The aggregate demand - at least in a closed economy - is composed of demand for consumer goods and demand for investments, both from the public and from the government.

7) Essay on Population, 1798. 
Aggregate consumption and savings are functions of real national. income ${ }^{b}$. At the same time Keynes formulates his well-known consumptionfunction which shows essentially that the marginal propensity to consume is smaller than 1 .

This means that the increase of aggregate consumption is smaller than the increase of national income. This function characteristics are derived by Keynes from a certain psychological apriorism in the matter of the consumer's attitude and elementary indications of budget studies. If the marginal propensity to consume is smaller than the increase of national income, then the gap between income and consumption in absolute terms will increase together witb income. Whether this gap also widens in relative terms depends on the variability of the marginal and average consumption propensities (i.e., the ratio between total consumption and national income); According to Keynes, the marginal propensity to consume itself will decrease when national income increases. As for the average consumption propensity, Keynes accepts that its figure also decreases when income increases. The possibility of a constant average consumption propensity is there for not restrained by him explicity.

Investments on the other hand, are a function of the marginal efficiency of capital, that is the anticipated output of an extra investment expenditure on the one hand and the height of the interest level on the other hand.

Another important function in the Keynesian system concerns the relation between liquidity preefrence (and so the money demand) on the one hand and the rate of interest and a number of liquidity motives on the other hand. The whole Keynesian theory is therefor based upon these four functions: (consumption, savings, investment, and liquidity) and upon the identity: national income $=$ consumption + investment. The normative conclusion which Keynes derives from his analysis is that demand must be stimulated to bring the macro-economic equilibrium up to the level of full employment. Froduction alone is no solution if demand shows insufficient absorption ability. The propensity is the variable easiest to influence through economic policy, according to Keynes. The action of the multiplier however facilitates expansive movement of economic activity.

8) Keynes reasons in real terms; all the used macro-economic quantities expressed in nominal terms are deflated. 
This multiplier-effect fulfils an essential part in the Keynesian system. R. F. Kahn" discovered in 1931 the existence of the "employment multiplier", an effect which means that a given initial increase of employment in one sector (e.g. public works) makes a manifold increase of totai employment. Keynes saw that this mechanism could also be in the relation between investment and national income. If investment is increased by an amount $x$ then the national income - under certain circumstances such as the elacticity of supply - will increase by an amount k.x. in which $\mathrm{k}$ is the multiplier (greater than 1.). The size of the multiplier depens on the size of the marginal propensity to consume. Ihe more consumed out of an income increase, the larger the multipliereffect will be on national income. However this effect is counteracted. by a number of "leaks", such as savings, imports, government taxes and stocks.

It is obvious that a policy of active government spending (such as. President Roosevelt's) could find a strong argument in the multiplier mechanism.

Since the thirties, Keynesian theory started an unfinished discussion. At first Keynes was attacked by authors who had sworn by classical theory in spite of the fact that the economic palicy they inspired could not slow down the great depression in any way. The criticism from the anti-Keynessians was led by A.C. Pigou ${ }^{10}$, F. Knight ${ }^{11}$, G. Cassel ${ }^{12}$, and others. Keynes took their criticism philosophically. In his General Iheory he had written: "Those who are strongly wedded to what I shall call 'the classical theory' will fluctuate, I expect, between a belief that I am. quite wrong and a belief tha I am saying nothing new!"

On the other hand Keynes immediately got the support of economists like J. Viner, J. R. Hicks (with some reservations), A. Lerner, A. Hansen, R. Harrod, L. Klein, H. Haberler, D. Dillard, O. Lange, etc....

9) Kahn, R. F., "The relation of home investment to unemployment". Economic Journal, June 1931.

10) Pigou, A. C., "Mr. J. M. Keynes' General Theory of Employmenc, "oterest and Money", Economica, vol. Ill, 1936.

11) "Knight, F., "Unemployment and Mr. Keynes' revolution in econo. mic theory", Canadian Journal of Economics and Political Science, vol. trl, 1937.

12) Cassel, G., "Mr. Keynes' General Theory", International Labour" Review, vol. 36, 1937. 
After the second world-war post and neo-Keynesianism developed. Nunerous authors (D. Domar, W. J, Baumol; P. A. Samuelson, R. Harrod. N. Kaldor, G. Ackley, K. Kurihara) tried to reduce the assumptions made by Keynes. These supposedly troublesome assumptions, within which Keynesian theory was constructed, can be reduced to six.

- The evolution of wariables in time is not taken into account by Keynes. This finds expression in Keynes' opinion about the multiplier.

His theory concentrates on short run ("in the long run we are all dead")

- Keynes supposes that physical capital goods stay constan:

- Goods and factor markets both are considered as competitive.

- All variables are expressed in real terms the influence of nominal values on behavior patterns is not considered.

- The macro-economic mechanism is expected to occur mainly in a closed economy.

The post-Keynesians have attached much importance to the action of the multiplier (e.g. R. Goodwin and C.P. Kindelberger). Also the influence of the accelerator-effect was stressed ( $F$. Harrod A. Hansen). The accelerator tries to quantify the influence from an increase in national income or an increase in the demand for consumer goods, on the demand for investment goods.

Finally, in the recent past, much attention has been centered on the empirical validity of Keynesian consumption function. Not only the absolute, but also the relative (J. Duesenberry) and the permanent (M. Friedman) income hypotheses have been formulated and tested. The influence of short and long run on consumption has also been examined (F. Modigliani, S. Kuznets).

Keynes' General Theory would never have been published withou+ the great depression. Its publication is doubtless the most important event in the history of economic thought in this century. Since then although not all economists have become or remained Keynesians, they have all become better economists. 


\section{sI. A Modified Conception of Money Functions and Interest.}

It is not accidental that in 1936, the English translation appeared of K. Wicksell's book "Geldzing und Giiterpreise". He was the founder of the Swedish School and his book was first published in 1893. The opinions of Wicksell, according to the distortion between monetary rent and natural rent. breaks not only monetary equilibrium, but also the equality between savings and investment and therefore the equality between demand and output as well, met a wide response in the thirties: Wicksell had a great influence on Keynes ${ }^{13}$.

One idea was that money is no longer neutral but on the contrary has a decisive influence on the "real dimension" of economic processes and that the part of money creating institutions is especially important.

Leading has the School of Stockholm with G. Myrdal, B. Ohlin, E. Lundberg ${ }^{14}$, and E. Lindahl ${ }^{15}$.

Keynes writes in his' General Theory : "The rate of interest is not the "price" which brings into equilibrium the demand for resources to invest with the readiness to abstain from present consumption. It is the price which equilibrates the desire to hold wealth in the from of casl with the available quantity of cash"16.

This view brought Keynes to the conclusion - already mentioned earler - that the rate of interest does not regulate the relations between savings and investment. Savings is, a residue and becomes ex-post equal to investment after adjustment of the national income. The rate of interest, on the contrary, results from a meeting of the liquidity preference with the money supply (created by the banking system's creation of money). Keynes' view is no doubt too monetary. He even admitted later (in 1987) that savings can have an influence on the rate of interest.

The importance of this theory $\rightarrow$ in the light of the great depression - is nevertheless that decreasing the rate of interest increases demand. The latter becomes competitive with the demand for investment

13) Keynes himself quotes the German economist S. Gesell (18\%: 1930 ) as the predecessor of modern interest theory. He greets him as "ar unduly neglected prophet."

14) Studies in the Theory of Economic Expansion, 1937.

15) Studies in the Theory of Money and Capital, 1939.

16) op. cit., p. 167 . 
resources. Only a stimulation of aggregate demand can avoid, in this case, a deflationary contraction.

As for the explanation of purchasing power of money, Keynes' great merit is that he integrated the quantity theory of money (amended by the School of Cambridge) into macro-economic theory concerning national income and employment. When there is unemployment and an elastic production output, thet an increase of money volume will increase real demand, and national income can increase without a rise in prices. On the other hand, (full employment, inelastic out-put and bettlenecks), an increase in money volume will produce only inflationary effects.

\section{A Renewed Explanation of Business - Cycle.}

The economic depression obliged many economists to reflect again on the business-cycle phenomenon. Harvard's tradecycle barometer had not seemed able to foretell the great depression.

The classical belief in J. B. Sya's "loi des débouchés" led to a negation of buciness - cycle. At most, the classicists accepted a temporary macro-economic disequilibrium under the influence of external factors. (structural disequilibrium caused by technogocial changes).

The Keynesians - in the wide sense - considered the businesscycle, with its upswings and downswings, its booms and turning points, as inherent in the economic system. In oppisiton to the classicists they aimed at an endogeneous explanation of the trade-cvvle. He has especially referred to the attitude of effective demand, the relation between savings and investment and the accelerator effect. This last effect (the influence of variation in demand for final goods on demand for investment goods) is particularly important for explaining the turning point of the business-cycle. The cumulative action of multiplier and accelerator were thought responsible for the expanding and contracting phases of business-cyle.

This analysis of cumulative processes in the economy had already been announced by G. Wicksell. The study of time-variables had came to the front even before Keynes. Here the role of the Swedish School must be underlined once more. G. Myrdal, B. Ohlin, K. Hammarskjöld ("on the spread of conjunctures") and E. Lundherg acquired their reputations by stressing anticipations, ex-ante-ex-post oppositions and their 
elaboration of period or sequence-analysis. On the same track, J. R. Hicks introduced the idea of elasticity of expectations.

Although Keynes himself did not offer a clearly defined businesscycle theory, a whole group of his contemporaries used the fundamental principles of the General Theory to contruct Keynesia business-cycle theories, although between themselves they may show important deviations. This is the case with. N. Kaldor, M. Kalecki, J. R. Hicks, R. F. Harrod, P. A. Samuelson, J. Tinbergen, J. W. Angell and A. Hansen. The latter author had published important writings on economic movements, before Keynes did so. So did J. Ackerman, who because of his global treatment of economic fluctuation holds an eminent place in economic theory. Finally our attention must be drawn to the voluminous work of L.H. Dupriez ${ }^{17}$ in which he tries to transcend the dichotomv between long and short run, which ortginated from the sharp contrast between classical (Say) and Keynesian theories. Dupriez especially emphasizes L. Walras's theory of general mutual interdependance.

By the thirties, a number of authors (R. F. Harrod, afterwards C. Cobb, P. Douglas and others) were interested in longer term perspectives. Thus materials were gathered for theories of economic growth. Numerous growth models were developed, particularly after World War II. :

\section{V. A new Theory of Economic Policy.}

Most spectacular no doubt was the new economic policy, which under pressure of the great depression was applied in most countries. In many cases a method of "trial and error" was followed. It was only later that the new theory of economic policy could be constructed.

In 1933 Fresident F. D. Roosevelt issued the National Industry Recovery Act as a part of his New Deal.

In Belgium the "plan of labour", was worked out mainly by the socialıst statesman $\mathrm{H}$. De Man, in an original attempt to assuage economic difficulties.

The theory of ecsnomic policy, created between 1930 and 1940, was again mainly influenced by Keynes. Resolutely, balanced governmental intervention in various domains was accepted. Economic policy became

17) Des Mouvement Economiqces Généreaux, 1947. 
subordinate to social policy especially in creating and maintaining ful ${ }^{r}$ employment. The Keynesians also emphasized the necessity of levelling: personal incomes, not only for social but also for economic reasons. An. income redistribution from the rich to the poor increases the propensity to consume and decreases the propensity to save, favoring the stimulation of aggregate demand.

The raising of aggregate demand depends upon demand for consumer goods and demand for investment goods.

Consumption is difficult to influence in the short run. This is due to the relative stability of consumption patterns. Consumption however can 'be stimulated, in Keynesian policy, by progressive fiscal measures, joining social payments, a policy of high wages, by discouraging sterile savmg, promoting consumption credit and increasing consumptive expenditures of the Covernment (deficit spending).

Investment takes a primary role in Keynesian policy. By so doing. savings must stream through to demand. If not, a deflationary danger starts. If investment is equal to aggregate ${ }^{i}$ savings, then, an economic is avoided, but an economic expansion is not yet produced. If investiment is smaller than aggregate ex-ante saving, then agregate demand becomes smaller than aggregate output. Equilibrium will be restored by a decrease of national praduct and national income: in this case an economic contraction occurs. If, on the contrary, investment is larger than ex - ante savings, aggregate demand becomes larger than aggregate output and. equilibrium, will be restored by an increase of national income and national product. Consequently an economic expansion develops. Economic policy must aim at the fact that investment surpasses. aggregate ex - ante saving.

Attaining a sufficient investment level seems to become more difficult when national income and hence welfare increase, due to the fact that savings increase relativelv with increasing national income. That is why the government must interfere to convert part of the savings into investment. This expantion, however is spontaneously promoted by the action of the multiplier and the accelerator. Investment can be stimulated in several ways. One is pressure on the interest level (cheap monev policy), by making it easier for industry to obtain credit. Another is providing fiscal exemption. A third is ameliorating marginal efficiency of capital which is possible if government policy inspires, confidence and firms ameliorate their productivity. A final method is direct government in- 
vestment, which, according to the Keynesian view, especially important because it put into operation the multiplier mechanism (pump priming).

As to international trade, the Keynesians are not unconditional supporters of free trade. They preach eventual protectionistic measures if this would protect the national economy against underemployment.

As to the budget, the Keynesians oppose yearly budget orthodoxy. They accept deficit spending and a more monetary financing of government expenditure. Fiscal policy, according to them, is no longer neutrat but must be handled as an active instrument of economic and social policy. This active expenditure and income policy of government is called "fiscal policy".

In relation to international economy, Keynes is opposed to the international gold standard, because through it, internal economic expan sion is sacrificed to the equilibrium of balance of payments. As a matter of fact, the international gold standard system restores equilibrium thanks to flexibility of prices and wages and eventually the decrease of employment. The Keynesians and all supporters of a socially motivated antideflationary policy consider decreased employment unacceptable. That is the reason for the pre - war attemts to temper or to eliminate the gold link of currencies.

The Keynesian theory of economic policy, developed in a period of depression, is no doubt inflationary. For these reasons, Keynesian - inspired economic policy had to be applied in a very cautious way in the perıod following World War II, due to the fact that this period was mainly characterized by creeping or sometimes avowedly inflationary tendancies. This revervation of Keynesian policy aims especially at smaller countrier, which export a great amount of their gross national product and which must pay great attention to restraining internal enflationary movements.

The fundamental objectives of today's economic policy can no longer be called purely Keynesian. In particular the theme of balanced growth is now stressed. It seems that economic policy-makers are especially concerned about realising the so-caller "magic pentagon", i.e.a. series of 5 economic and social goals :

- the maintenance o a full employment level.

- the realization of a just distribution and redistibution of national income. 
- the maintenance of a sufficient growth rate of gross national product.

- the relative stabilization of prices so as to guarantee the purchasing power of population and the competitive position on foreign markest.

- the prevention of an important balance of payments deficit.

The great difficulty here ise that objectives 1 and 3 are often contradictory to objectives 4 and 5 . The first mentioned objectives normally combine to produce inflationary tendencies. The second pair require an anti - inflationary policy. Here we find the painful dilemma of modern economic policy.

\section{A New Approach to Economic Systems. Criticism of Liberalism and Capitalism:}

The new economic policy and the economic conceptions by which it was supported, reinforced socialists and non - socialists alike in their criticism of traditional economic liberalism.

This was the case with Keynes himself but also with authors like J. A. Schumpeter ${ }^{18}$, W. Beveridge ${ }^{19}$, whose ideas penetrated especially before and during the second world war and A. Hansen ${ }^{20}$. P. Sweezy and E. J. Strachey ${ }^{21}$ took a more left - wing attitude in their analvsis of the great depression years. Condemning the unbridled capitalistic system did not, however, lead, to a new flare up of dogmatic Marxism in Western Europe. Rather, a new Marxism originated, attempting to re. concile government interventionism ${ }^{22}$ with parliamentary democracy, (e. a. L. Blum, French prime minister of the "Front Populaire" government 1936 - 37).

The famous book of $\mathrm{H}$. De Man "Au delà du Marxisme" (1929), pleaded for a modern socialist policy, inspired by the sociological changes of industrial society. It attracted a lot of attention. $O$. Lange tried to show, from a theoretical viewpoint, the possibility of decentralized socialism.

18) Capitalism, Socialism and Democracy.

19) The full employment in a free society, 1944.

20) Full Recovery or Stagnation, 1938.

21) The Nature of the Capitalistic Crises, 1935.

22) Lerner, A. P. Economics of Control, 1944. 
The "contestation" of economic liberalism drew in the thirties a reaction from many authors who called themselves neoliberals. The most 'well known are F. von Hayek ${ }^{23}$, 1. von Mises, L. Robbins, W: Eucken, W. Röpke, W. Lippman ${ }^{24}$, J. Rueff, L. Baudin and A. C. Pigou ${ }^{25}$.

Especially important is the so - called ordo - liberalism, defended by the Freiburger Schule, by which government interventionism is thought desirable as long as it conforms to the market mechanism and contributes to maintaining a situation of sufficient competition.

It is no doubt superfluous to point to the direct influence of the great depression on more avowedly' political doctrines like fascism, nạzism and neo - corporatism.

VI. A New Micro-Economic Analysis : The Theories of Imperfect and Monopolistie Competition.

Neither did micro - emonomic theory escape the maelstrom caused by the great depression. Pure competition situations and perfect market mechanismes had been the nearly exclusive reasoning hypotheses of the classical and marginal economists (sometimes called neo - classics) a. g. the School of Cambridge qith S. Jevons, Y. Edgeworth and A. Marshall and the School of Lausanne with L. Walras and W. Pareto.

The theory of imperfect competition has grown from a discussion about the real course of marginal and average costs in the firm $\mathrm{J} . \mathrm{H}$. Clapham had already referred in his famous article "On empty economic boxes" (1922) to the unrealistic character of the theory of the firm. In 1926, $\cdot$ P. Straffa turned his attention to the fact that many firms produce with decreasing marginal costs as a result of economics of scale. In "such a case however a stable micro - economic equilibrium is impossible if one clings to the hypothesis of pure competition. Then marginal and average revenue are constant, so that, when marginal costs decrease, produc:ioh expansion seems unlimited and equilibrium unattainable. This paradox was solved in the thirties by accepting that in many market circumstances the sales possibilities of the firm are limited. Average and marginal revenues become a decreasing function of sales, by which

\footnotetext{
23) The Road to Serfdom.

24) The Cood Society, 1937.

.25) Socialism versus Capitalism, 1939.
} 
a new stable equilibrium can originate, even when marginal costs decrease.

Such a view implies that every firm disposes on the market with a limited radius of actions within which a certain price autonomy is possible. At the same time this opiniom leads to disrupting industry into beterageneous markets and situations of imperfect or monopolistic competition.

So, a completely new micro - economic price and busiress theory came into existence, mainly thanks to the pioneering work of Cham${\text { be } l i n^{26}}^{26}$ Mrs. J. Robinson ${ }^{27}$ and H. von Strackelberg ${ }^{28}$.

It would be exaggerated of claim that the opinions of these authors. were directly influenced by the great depression, but they became closely affiliated with the spirit of times. For the presence of imperfect, oligopolistic or monopolistic competition prevents the automatic reaction of the welfare optimum (thanks to a liberal market economy). These ideas and also a number of Keynesian points of view were assimilated in the remarkable book of J. R. Hiks "Value and Capital" published in 1939. In 1940 R. Triffin published his famous work "Monopolistic competition and general equilibrium theory" in which attention is drawn on the theory of oligopoly and the criteria which must define different market forms.

VH. The Definition of Macro-Economic Relations : National Income Accounting and Input-Output Analysis.

During the great depression the need grew for valuable statistical information about macro-economic quantities. The Keynesian view of macro - economic coherence and business cycles stimulated the elaboration of a system of national accounts Pioneers in this domain were C. Clark, S. Kuznets ${ }^{29}$, J. Meade J. R. Stone and T. Barna. Particularly since World War II, with rather general acceptance o feconomic programmings. macro economic accounting has been used in most industiral states. Pioneering here was the American example of national accounts: and the input - output analysis of W. Leontief ${ }^{30}$. With this input - output

26) The Theory of Monopolistic Competition, 1932.

27) The Economics of Imperfect Competition, 1933.

28) Marktform und Gleichgewicht.

29) Studies in Income and Fealth, 1938.

30) The Structure of American Economy, 1941. 
analysis, an attemps is made to define the quantitative relations for the whole economy between the use of input factors and output goods and services. So, a concrete empirical content has been given to L. Walras concept of general interdependance.

\section{VIBI. The Origin and Break-Through of Econometries.}

Immediately connacted to the foregoing, the Fourdation in 1930 of ahe "Econometric Sociaty" at the initiative of. J.A. Schumpeter and Fischer deserves to be mentionad. The pitiful failure of the Harvard barometer's forecasting of business cycles and a certain suspicion for overly theoretical and deductive reasoning, had incited a number of economists to aim at a generalized quantification of economic data. The application of mathematics, in case of calculus, matrix algebra and, in the more revent past, of methods of set theory, was considered a guarantee of objectivity and scientific explanation of economic phenonena The most famous econometrician of this period is R. Frisch, who founded the review "Econometrica" in 1933. The fame of J. Tinbergen, T. Koopsuans and C. Tintner would spread after the war.

Econometrics however is more than an empirical technique. At first it was used as and ait to economic theory, but now econometrics seems to be absorbing economic theory. When quantifying the relations, which according to theory exist between economic phenomena, econometrics often constructs a system of equations which are called models. Once the equations are spccified, then econometricians will move to empirical valuation of the parameters.

The fact that two of the most important pioneers of econometrics from the thirties, namely $R$. Rrisch and $J$. Tinbergen have been proclainied the 1969 Nobel prize winners is certainly not accidental.

1X. Decay of the Theory and Practice of The International Gold Standard.

As for international monetary events, the period berween the two world wars has been extremely stirring and for most countries occasionally precarious. A lack of international cooperation and some very clear governmental mistakes no doubt contributed to the beginning of the great depression and to the extent of its development. 
Between 1920 and 1925 attempts were made to restrain inflation with the classical recipe of a deflationary policy (e. a. by $R$. Poincaré. form France).

In Great Britian, the then Chancellor of the Exchequer, W. Churc-hill, decided to revalue Pound Sterling. This policy led to complete failure in 1931 and 1932 when Great Britain was obliged to give up the. gold - parity and to end its policy of international free - trade. These troubles found exression at the conference of Ottawa from which grew the "imperial preferences" with respect to the Commonwealth countries.

The payments for wor domages to which Germany was condemned. had to be reduced (Dawes and Young Plans). In 1933 President F. D. Roosevelt decreed suspension of the Gold Standard of the dollar. In 1934 the dollar was devalued by $41 \%$.

Heroic attempts of the "gold bloc" countries, headed by France, who tried to maintain the principles of a gold based international monetary system, failed in 1936. At that time the French also abandoned the gold standard and started a period of successive devaluations. These startling events had great influence on economic theories concerned with these matters.

The opinion grew that gold, not only as a basis of intern monay circulation, but also pillar of the international monetary system, would promote an unbearable situation.

Under the impulse of J.M. Keynes and A. Aftalion, but worked out by post - Keynesians like R. Nurkse, the classical opinions of D. Ricardo. and D. Hume regarding the International Gold Standard were renounced. The classical automatism stipulated that the rates of exchange only vary between gold points and that disequilibrium of balance of payments would be eliminated spontaneously, thanks to the flexibility of internal prices and wage levels. Apart from the political argument, according to which internal expansion should not be sacrificed for external equilibrium, the Keynesians defended the thesis that the equilibrium - restoration of balance of payments is realised via adjustment of National Income rather than through internal price variations. The extent to which the equilibrium will be restored, depends upon the relation between the export 
multiplier ${ }^{31}$, stimulating the home economic expansion, and the marginal import propansity ${ }^{32}$, accomplishing the role of a "leak".

Reconstruction of the international monetary system is not a post war problem. During the great depression, debates between supporters and opponents of the Gold Standard and the Gold Exchange Standard and a new system of fluctuating currencies were extremely intense.

Also dating from this period are a few ideas which would be worked out by Keynes in 1944 in his famous plan, defended at the Bretton Woods conference. The Keynes plan stressed the Central Bank functions of the International Monetary Fund.

\section{A New Turn In Theoretical Welfare Economics.}

Fianlly it can be said that the great depression and the economic policy which it spawned influenced what is now called "The new Welfare Economics".

Theoretical Welfare Economics tries to formulate conditions for optimizing welfare. Its conclusions could eventually be indicative of social policy.

At the beginning of the thirties, the views about welfare economics still seemed to be trangly under the influance of the neo - classical author A. C. Pigou. Pigou was a pupil of A. Marshall and, after Marshall's death, the became the leader of the School of Cambridge. Pigou had already published in 1920 an important work "The Economics of Welfare". Further editions were published in 1929 and 1932. In this book, Welfare is exclusively brought into relation with "the measuring rod of money". The increase of welfare was, according to Pigou, -in a static optic - the result of a more efficient use of factors of productions and of the redistribution of national income At the same time, an important distinction was made between social and private marginal utility.

The Pigovian welfare economics were later caller the "old welfare economics" because they were implicitly based on the classical idea that pure competition optimizes welfare. Besides, it was accepted - comple-

31) This is the influence of foreign demand on national income variation.

32) This is the relation between a variation of national income and the variation of import, streaming from it. 
tely in the Benthamian tradition - that utilities, of not measurable, are at least inter - individually comparable.

The "New Welfare Economics" came into existence in the thirties as a reaction to Pligou, and more particularly as a result of the views developed by B. Pateto around the vears 1900 .

Considered from a historical - genetical side, "the new welfare economics" are old, and even older than the so-caller "old welfare economics".

Pareto's opinion was ordinal. This means that utilities are not considered cardinally measurable and therefors neither interpersonally comparable... The famous Pareto - optimum states that welfare is at a maximum only when it is possible to improve the situation of person $A$ by worsening the situation of person B. Market economy leads, via career, to the realisation of a number of Paretion optimums (the contract - curve), between which choice, from a social view, is impossible as long as the question of the interindividual comparability of satisfaction if not solved.

N. Kaldor ${ }^{33}$ and J. R. Hiks ${ }^{34}$ meant that this difficulty could be neutralized by the use of the compensation principle. Person $B$, whose situation has bean worsened by redistribution, must be compensated. If $\mathrm{A}$ is still beter off after this then social welafre has increased.

T. Scitovsky claimed however that the compensation principle leads to contradictions.

A few authors also tried to apply Pareto - criteria to the organization of a socialist economy. How nationalized industrics in general, and public utilities in particular - whose role increased steadily durig the thirties - colud benefit from application of the marginal cost rule, was examined in more detail. Important here are the publications of A.P. Lerner $^{35}$, culminating in his master work "The Economics of Control"

33) In "Welfare propositions in economics and interpersonal comps?risons of utility" Economic Journal, 1939. 1949.

34) In "The foundations of welfare economics," Economic Journal,

35) "Economic theory and socialist economies". Review of Economis Studies, 34; "Statics and Dynamics in socialist economics" Economic Journal 193\%, which were published in the book "The Economics of Control: Principles of Welfare Economics" (Mac Millan 1944).

36) In "The general welfare in relation to problems of taxation and of railway and utility rates", Econometrica, 1938. 
Finally and important article published by A. Bergson in 1938 deserves to be mantioned ${ }^{37}$. Bergson theorizes that individual and collective value judgments about social organisation are an integrated element of the social welfare function. Through this opinion economic theory began taking into account the very divesging points of view regarding the ideal organization of society, which were born since the great depression.

In the following decades, welfare economics wolud be worked out to an impressive point by P.A. Samuelson, T. Scikovsky, K. J. Arrow, J. R. Hiks, G. Debreu, T. Koopmans, J. E. Meade, R. Dorfman and R. Solow. With these authors however we land in the actual development of economic theory.

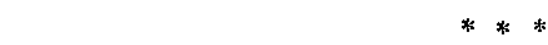

Seldom has such a short preiod, like the thirties, been so fertile for economic thought. Of all the authors who hvae led economic theory to new roads under the pressure of current events. Keynes is no doubt the most important figure.

His influence on economic science has been compared with that of A. Einstein on physics. About his principal work General Theory the astute P. A. Samuelson wrote: "It is a badly written book, poorly organized... It is arrogant, bad - tempered, polemical... It abouds mares' nest and confusions... but when finally mastered, we find its analysis to be obvious and at the same time new. In short, it is the work of a genius."

Now, i n1970, with that "black Friday" nearly 40 years past, the economic situation of the Western world has changed enormously. The economists of our time face rather the endless disease of inflation, then the curse of deflation. Moreover the Keynesian recipes can not be applied without reservation, padticularly in small countries.

However it is indisputable that the great depression has made an indelible imprint on economic science.

37) "A reformulation of certain aspects of welfare economics" Quarterly Journal of Economics, 1938. 